\title{
Gene structure and expression of the $\mathrm{Mbol}$ restriction - modification system
}

Takashi Ueno, Hiroyuki Ito*, Fusao Kimizuka, Hirokazu Kotani and Kazuo Nakajima Bioproducts Development Center, Takara Shuzo Co., Ltd, Seta 3-4-1, Otsu, Shiga 520-21, Japan

\begin{abstract}
The genes from Moraxella bovis encoding the Mbol restriction-modification system were cloned and expressed in Escherichia coli. Three open reading frames were found in the sequence containing the genes. These genes, which we named $m b o A, m b o B$, and $m b o C$, had the same orientation in the genome. Genes $\mathbf{m b o A}$ and $\mathbf{m b o C}$ encoded $M$ bol methyltransferases (named M.MboA and M.MboC) with 294 and 273 amino acid residues, respectively. The mboB gene coded for Mbol restriction endonuclease (R.Mbol) with 280 amino acid residues. Recombinant E.coli-MBOI, which contained the whole Mbol system, overproduced R.Mbol. R.Mbol activity from E.coli-MBOl was 480 -fold that of M.bovis. The amino acid sequences deduced from these genes were compared with those of other restriction-modification systems. The protein sequences of the Mbol system had $38-49 \%$ homology with those of the Dpnll system.
\end{abstract}

\section{INTRODUCTION}

Restriction endonucleases are needed for the molecular cloning of genes. Many restriction-modification systems have been discovered in a wide variety of microorganisms (1), where they protect the host from invasion by foreign DNA. More than 100 genes encoding restriction-modification systems have been cloned and expressed in Escherichia coli $(2,3)$. Moraxella bovis, which are facultative anaerobic and Gram-negative rods (4), have two restriction-modification systems, $M b o \mathrm{I}$ and $\mathrm{MboII}$, which recognize double-stranded DNA at the sequences 5'-GATC-3' and $5^{\prime}$-GAAGA-3', respectively (5). The genes encoding the $M b o$ II system have been cloned and sequenced (6).

The Sau3AI system (7), the DpnII system (8, 9), DpnI endonuclease (8), and Dam methylase (10) recognize the same DNA sequence as the MboI system. The structures of genes encoding their enzymes, except the genes for the MboI system, have been identified. Comparison of these enzymes may help to elucidate some general rules for DNA sequence recognition and cleavage.

$M b o I$ endonuclease (R.MboI) is one of the most widely used enzymes for molecular biology and was purified from M.bovis by Gelinas et al. (5). Cloning and expression of the R.MboI gene in E.coli will make it possible to obtain pure preparations of the enzyme in large amounts.

In this paper, we report the cloning of the genes coding for the MboI system and the expression of R.MboI in E.coli. The amino acid sequences predicted from the genes were compared with those of other restriction-modification systems.

\section{MATERIALS AND METHODS}

Enzymes and chemicals

Restriction endonucleases, modification enzymes, and kits for DNA sequencing, kilo-sequence deletion, 5 '-end labeling, blunting, and ligation were products of Takara Shuzo Co., Ltd. (Kyoto, Japan), and were used according to the manufacturer's instructions.

Bacterial strains, plasmids, phages, and DNA preparation M.bovis (ATCC 10900) was purchased from the American Type Culture Collection. E.coli strains GM33 [sup85, dam3 (11)], HB101 $\left[F^{-}, h s d S 20\left(r^{-}, m B^{-}\right)\right.$, supE44, aral4, $l^{-}$, galK2, lacYl, proA2, rpsL20, xyl-5, mtl-1, recA13 (12)], and JM109 [recAl, endA1, gyrA96, thi, hsdR17 $\left(r K^{-}, m K^{-}\right)$, supE44, relA1, $l^{-}, D$ (lac-proAB), $F^{\prime}$, traD36, proAB, laclqZDM15 (13)] and plasmids pBR322 [Tcr $\left.\mathrm{Tp}^{\mathrm{r}}(14)\right], \mathrm{pACYC} 184\left[\mathrm{Cm}^{\mathrm{r}}, \mathrm{Tc}^{\mathrm{r}}(15)\right]$, pUC18 [Ap $\left.{ }^{\mathrm{r}}(13)\right], \mathrm{pUC19}$ [Ap $\left.{ }^{\mathrm{r}}(13)\right], \mathrm{pKH} 1$ [Ap $\left.^{\mathrm{r}}(16)\right]$, and pNT203 [ $\operatorname{Tc}^{r}$ (17)] were the host-vector systems used for cloning and expression. M13mp18 and mp19 (13) were used for DNA sequencing. E. coli competent cells were produced by the procedure of Hanahan (18). $\lambda$ virulent phage $(\lambda \mathrm{gt} \cdot \lambda \mathrm{c})$ was prepared from plate lysates. E. coli plasmid DNA was prepared on a small scale by the method of Birnboim and Doly (19). M.bovis chromosomal DNA was purified by the procedure of Ausubel et al. (20).

Construction of the M.bovis genomic library

An AluI partial digest of chromosomal DNA was fractionated with agarose gel electrophoresis, giving fragments from 4 to 7 (kb) long. The fragments were ligated to the EcoRV site of plasmid pBR322 and used to transform E.coli GM33 (Dam-).

\footnotetext{
* Present address: Department of Bioscience and Chemistry, Faculty of Agriculture, Hokkaido University, Sapporo 060, Japan
} 


\section{Screening of the MboI methyltransferase gene}

Total plasmids were prepared from the transformed E.coli GM33 cells and digested with an excess of R.MboI. E.coli GM33 was transformed again with the digested plasmids. The transformants obtained were plated onto L-plates (21) containing $100 \mu \mathrm{g} / \mathrm{ml}$ ampicillin. Plasmids were prepared from the surviving bacterial cells and analyzed for their ability to express $\mathrm{MboI}$ methyltransferase. A recombinant plasmid, pUM1, with a 4-kb insert was isolated and subcloned into pUC19 to yield plasmid pUM2. This plasmid was used for the construction of a series of deletion clones (pUM2-d1 to pUM2-d6; Fig. 1).

\section{Analysis of N-terminal amino acid sequences}

R.MboI was partially purified from a culture of $M$.bovis by the method of Gelinas et al. (5). The N-terminal amino acids were sequenced as described elsewhere $(22,23)$.

\section{Screening for MboI system genes}

A DNA probe (23-mer) was synthesized based on the N-terminal amino acid sequences of R.MboI for the screening of genes encoding the MboI system. After the probe was labeled with [ $\gamma^{-32}$ P]ATP and the kit for 5'-end labeling (Megalabel, Takara), it was used for genomic Southern hybridization as described elsewhere (23). A 5.1-kb BglII-NdeI fragment was isolated, bluntended, and cloned into the pUC18 vector to yield a plasmid, pMBO1. E.coli JM109 $\left(\mathrm{Dam}^{+}\right)$cells carrying pMBO1 were assayed for their ability to produce R.MboI and M.MboI, and then used for the construction of a series of deletion clones (pMBO1-d1 to pMBO1-d7; Fig. 1).

\section{Assay of enzyme activities}

R.MboI activity in vivo was estimated from the plating efficiency of $\lambda$ virulent phage. In vitro, activity was assayed by the incubation at $37^{\circ} \mathrm{C}$ of $25 \mu \mathrm{l}$ of a reaction mixture containing 20 $\mathrm{mM}$ Tris- $\mathrm{HCl}$ (pH 8.5), $10 \mathrm{mM} \mathrm{MgCl}, 1 \mathrm{mM}$ DTT, $100 \mathrm{mM}$ $\mathrm{KCl}, 1 \mu \mathrm{g}$ of $\mathrm{N}^{6}$-methyladenine-free $\lambda \mathrm{DNA}$, and the enzyme solution. One unit of enzyme activity was defined as the amount of enzyme needed for complete digestion of $1 \mu \mathrm{g}$ of $\mathrm{N}^{6}$-methyladenine-free $\lambda$ DNA at $37^{\circ} \mathrm{C}$ for $1 \mathrm{hr}$. Mbol methyltransferase activity was assayed in vivo by the resistance of plasmids to R.MboI digestion. This activity was assayed in vitro by the incubation of $10 \mu \mathrm{l}$ of $50 \mathrm{mM}$ Tris $-\mathrm{HCl}(\mathrm{pH} 7.5)$ containing $5 \mathrm{mM}$ 2-mercaptoethanol, $10 \mathrm{mM}$ EDTA, $80 \mathrm{mM}$ $S$-adenosylmethionine, $1 \mu \mathrm{g}$ of $\mathrm{N}^{6}$-methyladenine-free $\lambda$ DNA, and the enzyme solution at various concentrations for $1 \mathrm{hr}$ at $37^{\circ} \mathrm{C}$. Then $40 \mu \mathrm{l}$ of a reaction mixture containing R.MboI was added and the mixture was incubated at $37^{\circ} \mathrm{C}$ until digestion was complete. One unit of enzyme activity was defined as the amount of enzyme needed for complete protection from digestion by R.MboI for $1 \mathrm{hr}$ of $1 \mu \mathrm{g}$ of $\mathrm{N}^{6}$-methyladenine-free $\lambda$ DNA.

Deletion assays were done as follows. A series of deletion mutants was prepared with a kilo-sequence deletion kit and introduced into E.coli. The activities of the two enzymes from the clones were assayed in vivo and in vitro as described above.

\section{Nucleotide sequencing}

Nucleotide sequencing was done by the dideoxy chain termination method (24), except that 7-deaza-dGTP was used instead of dGTP. Restriction fragments were isolated from the MboI restriction-modification genes and subcloned into the appropriate sites of the vectors $\mathrm{M} 13 \mathrm{mp} 18$ or mp19. Alternatively, deletion derivatives were generated from subclones containing the $\mathrm{MboI}$ system with a kilo-sequence deletion kit. The sequences were deduced from the results for both strands. The DNA sequences and the predicted amino acid sequences were analyzed by a computer-aided system for DNA analysis (DNASIS, Hitachi, Japan).

\section{Construction of plasmids for overproduction of R.MboI}

A PvuII fragment of the plasmid pUM2-d4 was ligated with the EcoRV site of the pACYC184 vector. The plasmid obtained, $\mathrm{pMBOC}$, included a lac promoter and the mboC gene region from pUM2-d4 (Fig. 2A). An EcoRI-XmnI fragment from the pMBO1-d2 plasmid (Fig. 1) and the BglII-EcoRI linker (Fig. 2B) were ligated with $\mathrm{pKH} 1$ vector, which had been digested with $E c o$ RI, blunt-ended with a blunting kit, and digested with $B g l \Pi$. The resulting plasmid, $\mathrm{pMBOAB}$, contained the $m b o \mathrm{~A}$ and $m b o \mathrm{~B}$ genes. Both pMBOC and PMBOAB plasmids were introduced into E.coli HB101 together with the plasmid pNT203 for overproduction of R.MboI.

The E.coli recombinants obtained, named E.coli-MBOI, were cultured in $20 \mathrm{ml}$ of LB broth (21) containing $100 \mu \mathrm{g} / \mathrm{ml}$ ampicillin, $30 \mu \mathrm{g} / \mathrm{ml}$ chloramphenicol, and $15 \mu \mathrm{g} / \mathrm{ml}$ tetracycline at $30^{\circ} \mathrm{C}$ until the absorbance at $600 \mathrm{~nm}$ was $1.0-2.0$, heated at $42^{\circ} \mathrm{C}$ for $15 \mathrm{~min}$, and cultured at $37^{\circ} \mathrm{C}$ for $5 \mathrm{hr}$. The cells were harvested, suspended in 4 volumes of a buffer $[20 \mathrm{mM}$ potassium phosphate (pH 7.5) containing $10 \mathrm{mM}$ 2-mercaptoethanol, $5 \%$ glycerol, and $0.15 \%$ Triton X-100], sonicated for $10 \mathrm{~min}$, and centrifuged at $100,000 \times g$ for $30 \mathrm{~min}$. The supernatant was assayed for R.MboI activity in vitro and checked for production of R.MboI by SDS-PAGE (Fig. 2C).

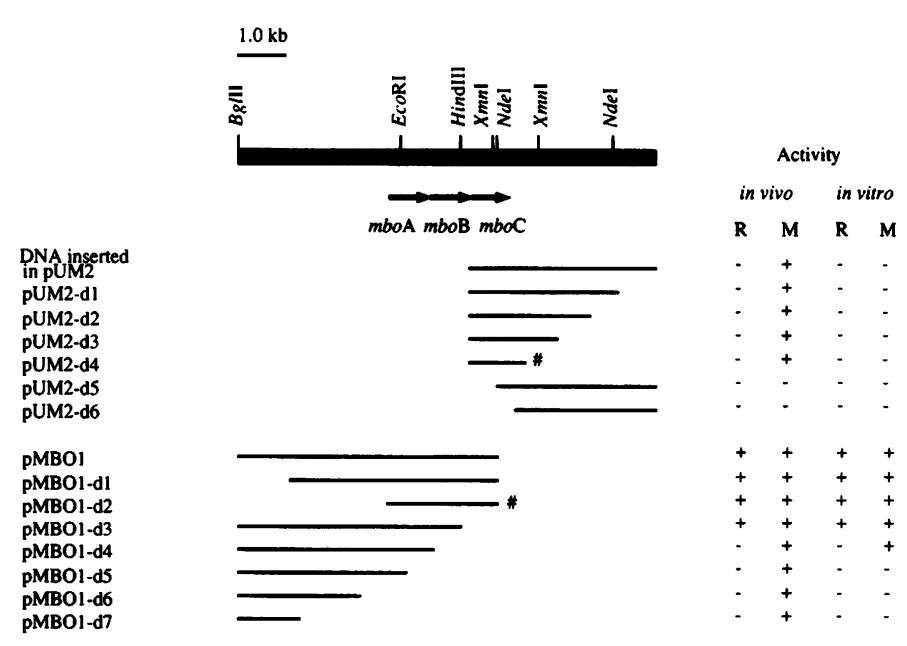

Figure 1. Restriction map and deletion analyses of PUM2 and pMBO1. Deletion derivatives, pUM2-d1, $-\mathrm{d} 2,-\mathrm{d} 3,-\mathrm{d} 4,-\mathrm{d} 5$, and $-\mathrm{d} 6$, of the fragment inserted in pUM2 and deletion derivatives, pMBO1-d1, $-\mathrm{d} 2,-\mathrm{d} 3,-\mathrm{d} 4,-\mathrm{d} 5,-\mathrm{d} 6$, and $-\mathrm{d} 7$, of the fragment inserted in PMBO1 were prepared with a kilo-sequence deletion kit. Enzyme activities were assayed in vivo and in vitro as described in 'Materials and Methods': +, detectable activity; - , no detectable activity; $\mathbf{R}$, restriction activity; M, modification activity; \#, the fragments sequenced. 


\section{SDS-PAGE}

SDS-PAGE was done by the method of Laemmli (25) with a $12.5 \%$ polyacrylamide slab gel. Phosphorylase $b\left(M_{r} 97,400\right)$, bovine serum albumin $(66,200)$, ovalbumin $(42,700)$, carbonic anhydrase $(31,000)$, soybean trypsin inhibitor $(21,500)$, and lysozyme $(14,400)$ were used as markers of molecular weight (Bio-Rad Labs).

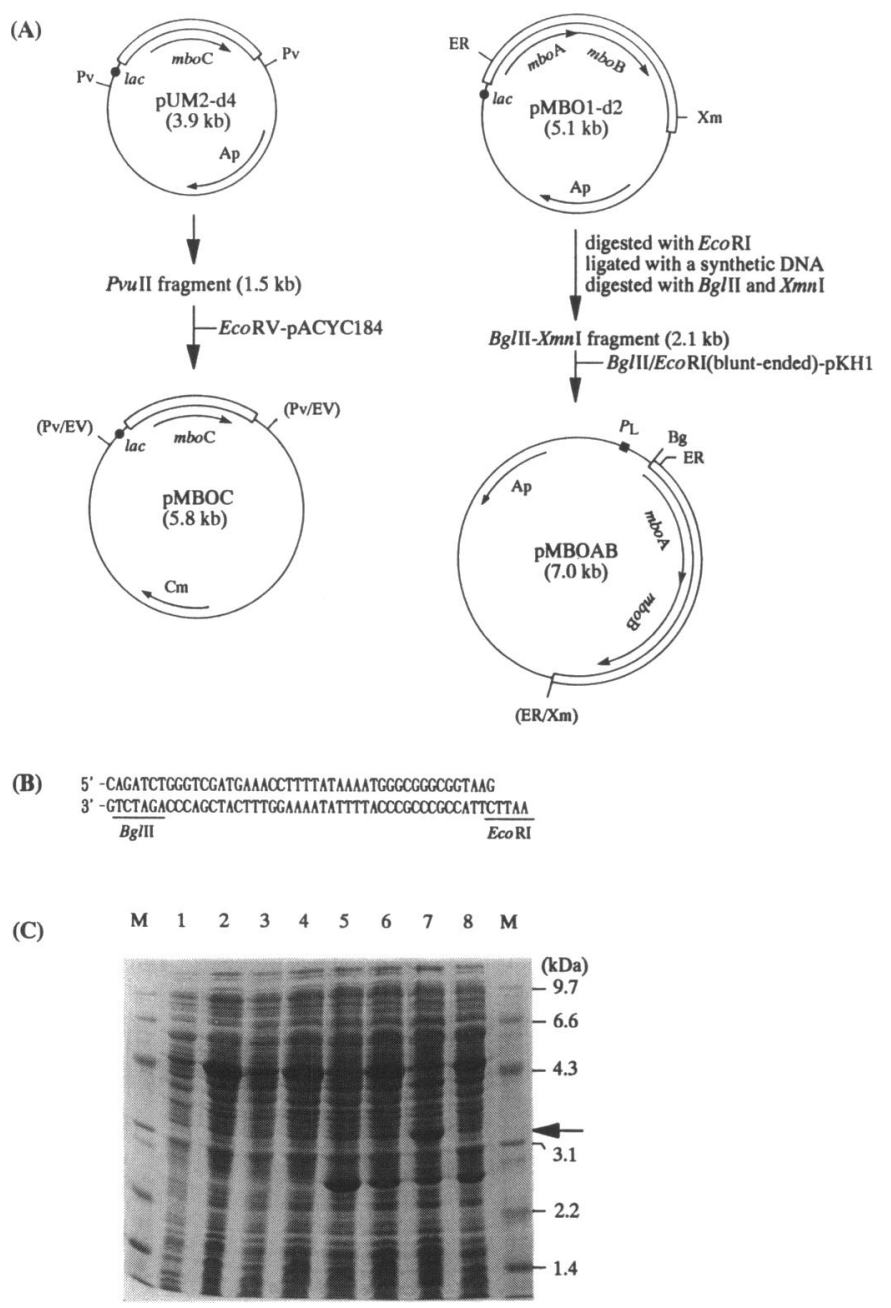

Figure 2. Construction of the plasmid pMBOAB and overproduction of R.MboI in E.coli-MBOI. (A), Plasmid pMBOC carried the mboC gene and a lac promoter region from plasmid pUM2-d4. Plasmid pMBOAB contained the $m b o A$ and $m b o B$ genes from plasmid $\mathrm{pMBO} 1-\mathrm{d} 2$ and $P \mathrm{~L}$ promoter from the vector $\mathrm{pKH} 1 . \mathrm{Bg}$, $B g l \mathrm{II}$; ER, EcoRI; EV, EcoRV; Pv, PvuII; Xm, XmnI; lac, lac promoter; PL, $P \mathrm{~L}$ promoter; $\mathrm{Ap}$, ampicillin resistance gene; $\mathrm{Cm}$, chloramphenicol resistance gene. (B), The nucleotide sequence of a synthetic DNA fragment for construction of plasmid pMBOAB. (C), Overproduction and estimation of the molecular weight of R.MboI. Lanes M, molecular weight markers; lane 1, E.coli HB101 with heatinduction; lane 2, E.coli $\mathrm{HB} 101$ without induction; lane 3, E.coli $\mathrm{HB} 101$ containing plasmid pNT203 with heat-induction; lane 4, E.coli HB101 containing plasmid pNT203 without induction; lane 5, E.coli HB101 containing plasmids pNT203 and pMBOC with heat-induction; lane $6, E$.coli $\mathrm{HB} 101$ containing pNT203 and pMBOC without induction; lane 7, E.coli HB101 containing pNT203, pMBOC, and $\mathrm{PMBOAB}$ with heat-induction; lane 8, E.coli HB101 containing pNT203, $\mathrm{pMBOC}$, and $\mathrm{PMBOAB}$ without induction. The arrow indicates the position of the molecular weight of R.MboI.
(A)

1) $4 . \mathrm{Mod}$

2) 4 Doll

3) Dia

1) $\mathrm{L} . \mathrm{Bbo \textrm {A }}$

2) L. D, DII

3) Da!

1) $\mathrm{L} . \mathrm{Hb} \mathrm{OA}$

2) L. Dpall

3) DaI

1) $\mathrm{l} . \mathrm{b} \mathrm{hod}$

2) K. Doll

3) Da1

1) $\mathrm{K} \cdot \boldsymbol{W} \mathrm{bod}$

2) L D,all

3) Das

(B)

1) I. $\mathrm{vb}$ o

5) $\mathrm{L}$ Dod

6) L. Biaf I

1) $x$.

5) $\mathrm{L}$. Do BA

6) Y. Biat I

1) $y$ ib

5) L. Dod

b) H. Biafl

1) I. $\operatorname{lod}$

5) L. Dou

f) Kr Biafl

1) $\mathrm{k} . \mathrm{HboC}$

5) L. Dod

f) V. Biaf I

f) Yy Biafl

(C)

1) R. $\mathrm{V} / \mathrm{O} \mathrm{I}$

8) R. DoII

7) R. $y b o l$

1) R. Doll

7) R. $\mathrm{Vb}$ oI

I) R. Doll

1) R. $y$ bol

f) R. Doll

7) R. Whol

1) R. Doll

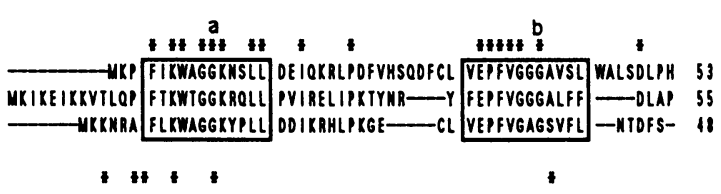

LKOLVINOCHADLINYYOYIKNNPDDLIGYIENLOSHYOKL TOLESXKCPFYHKROVFNORTSNOIE 120 - KDAVIOMFMAELIMCYOQIKOMPOELIE ILKVHOEYMSKEYYLDLRSA - DROERIOWYSEVOR 117 -RYILAOINSOLISLYWIVKMRTDEYVQAARELFVPETMCAEY-Y-YOFREEFMKSOOPFR III

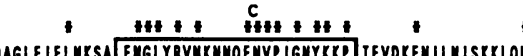

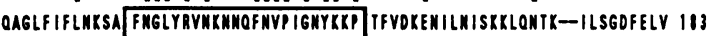

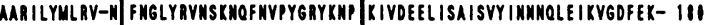
AV-LFLYLMRYG YNGLCRYWLRGEFWYPFGRYKKP YFPEAELYHFAER-AQEAFFYCESYADSW- 169

$$
+\ldots+\ldots+1+t
$$

LAHLPWNEPCL FYLOPYYR ISOTASFT SYSONGFDOUEOKRLANFCXXIOXLGHYFLLSNSOPK 211

-AIVOVRTGOF VYFOPPYIPLSETSAFT SF THEGFSFADQVRLRDAFKRLSDTGAYVMLSH- 211

-ARADDASV- UYCOPPYAPLSATANFT AYHTHSFTLEOQAHLAEIAEGLVERHIPVLISN- 227

$$
\text { * }
$$$$
+1
$$

MTNSSDEFFOELYQDFKIERIQANRTISANSHGRKKVNEIIVSHGV

-SSSALVEELYKDFNIHYVEATRTMGAKSSSRGKISEIIVTMYEK

- HDTML TREWYORAKL HYVKVRRS ISSNGg TRKKVDELLALYKPGVYSPAKK

-

$$
\text { the mat }
$$

MRIKPYFESDORNFWIYOGNCIOFUSHEODN SIDMIFADPPYF LSHOGLIFKMSIIO-SVMKGE IS

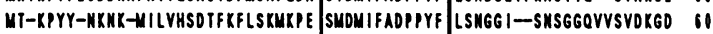
MII-KENI-NDFL-NTILKGOCIERLKTIPNE SIDLIFADPPYE MOTEGKLLRTNGDEF-SGVDE

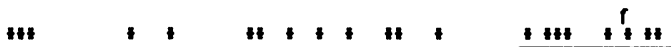

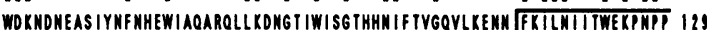

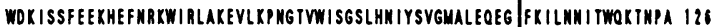
WOKF WDFVEYDSFCELWLKECKRILKSIGS IWVIGSFQN IYRIGY IWONLD EWILWOVIWMKTNPV 127

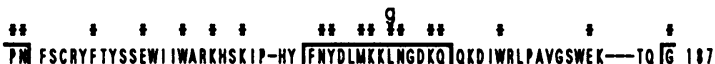

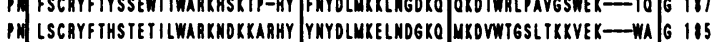

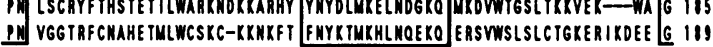

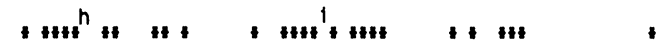
T-HPTOKPLGLSRIILSS IORO DLILDPFSGSGTT IAGVLLORMYIGIEOELEFLELSKRA 251 - -HP TOXPEYLLERIILAS IKEG OYILDPFVGSGTTG VVAKRLGRRFIGIOAEXEYLXIARKR 211 KKAHSTOKPESLLYKVILSS SKPN DVVLOPFFGTGIIG AVAKALGRHYIGIEREOKYIOVAEKR 253

YHEITPVLKNEFROKIRKOISAI

LEAEMETH

273

LRE IKPMPNDIELLSLEIKPPXVPMRTLIEADFLRVGQTLFOKMEMAICIVTODGNYKONEETLSIH 320

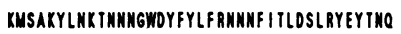

359

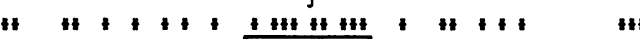

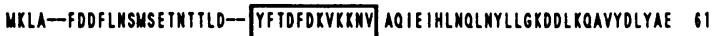

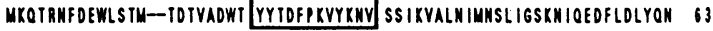

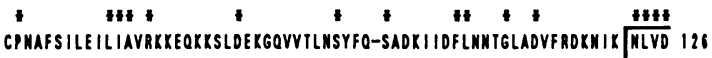
YPEILKVYPLLIAKRLRDTIIVKDPIKDFYFOFSKRMYSIEEYTMFLERSGIFOLLONHLVS NLVO 129

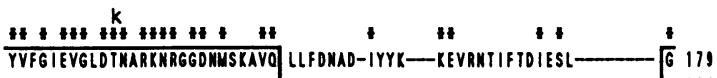
YVTGVEVGMOTMGRKNRTGOAMENIVO SYLEAEGYILGENLFKEIEOHEIEEIFSVDLSAITNO G 191

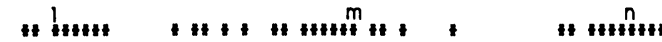

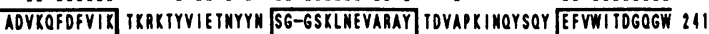
MTYKRFOFVIX] MEOVLYLIEVWFY- SGSGSKLLETARSY KMIAEETKAIPHV EFWWI TOGOGW 256

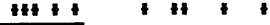

RTAKMKLOE AYTHIPSYYNLYTLHGFIEOLNSEGYIKOW 271

YKAKHNLRE TFOILPFLYNIMOLERWILKMLR

Figure 3. Alignments of M.MboA, M.DpnII, and E.coli Dam methylases (A), M.MboC, DpnA, and M.Hinfl methylases (B), and R.MboI and R.DpnII endonucleases (C). Identical amino acids of the methylases in $\mathrm{A}$ and $\mathrm{B}$ and of the endonucleases in $\mathrm{C}$ are indicated by asterisks. Bars show gaps in the aligned sequences. The highly conserved regions are boxed and labelled $\underline{a}$ to $\underline{n}$. 


\section{RESULTS AND DISCUSSION}

\section{Isolation of the $M b o I$ methyltransferase gene}

Selection of the gene encoding $M b o I$ methyltransferase was based on the resistance to digestion with R.MboI of self-modifying recombinant plasmids. One clone that expressed $M b o I$ methyltransferase was selected and subcloned into the pUC19 vector for the construction of a deletion series. The activities of $M b o I$ methyltransferase and endonuclease from the deletion clones were assayed in vivo and in vitro (Fig. 1). The region encoding MboI methyltransferase was found in the pUM2-d4 plasmid. Endonuclease activity was detected neither in vivo nor in vitro. Methyltransferase activity in vitro was not found; probably, it was not expressed at a high enough level for detection by our assay.

\section{Analysis of N-terminal sequence of R.MboI}

Thirty amino acids, Met- Lys- Leu- Ala- Phe- Asp- Asp- PheLeu- Asn- Ser- Met- Ser- Glu- Thr- Asn- Thr- Thr- Leu- AspVal- Phe- Thr- Asp- Phe- Asp- Lys- Val- Lys- Lys, were identified in the N-terminal sequence of purified R.MboI. A 23-mer DNA probe, 5'-ATGAAGITIGCITTTGATGATTT-3' (' $\mathrm{I}$ ' indicates inosine residues), was synthesized based on this $\mathrm{N}$ terminal sequence. The probe did not anneal with the pUM1 plasmid.

\section{Isolation of $\mathbf{M b o I}$ restriction-modification genes}

Plasmid pMBO1 was obtained by Southern hybridization with the synthetic probe. Endonuclease and methyltransferase activities in vivo and in vitro were detected in the clones that contained the pMBO1 plasmid (Fig. 1). Deletion mutants containing pMBO1-d1, -d2, -d3, and -d4 had methyltransferase activity either in vivo or in vitro. The mutants containing pMBO1-d5, $-\mathrm{d} 6$, and $-\mathrm{d} 7$ had only in vivo methyltransferase activity. The methyltransferase activity in vivo was probably that of the Dam methylase of host E.coli. The level of expression of Dam methylase is low, which probably explains why the activity was not found in vitro under our assay conditions. Therefore, we expected that there was another methyltransferase gene in pMBO1 and analyzed pMBO1-d2, which probably contained the endonuclease and methyltransferase genes.

\section{Gene structure of the MboI system}

Nucleotides of the fragments inserted in the pUM2-d4 and pMBO1-d2 plasmids were sequenced as described in 'Materials and methods'. The fragments inserted in the pUM2-d4 and pMBO1-d2 plasmids overlapped with each other. There were three open reading frames (ORFs) in the same direction in the combined nucleotide sequence, 2826 base pairs (bp) long (Fig. 1). The first and third ORFs, 885 bp long and coding for positions 137 to 1021 , and $822 \mathrm{bp}$ long and coding for positions 1867 to 2688 (termed $m b o A$ and $m b o C$, respectively) encoded methyltransferases (named M.MboA and M.MboC) of 294 and 273 amino acid residues $\left(M_{r} 33,700\right.$ and 31,900$)$, respectively. The second ORF, 843 bp long (1023 to 1865; the $m b o B$ gene) encoded a restriction endonuclease (R.MboI) of 280 residues $\left(M_{r} 32,200\right)$. The $\mathrm{N}$-terminal amino acid sequence deduced from the $m b o B$ gene was identical with that of purified R.MboI. There were putative Shine-Dalgarno (SD) sequences upstream of the three genes: GAAA at positions 126 to 129 for the mboA gene, GGAG at 1013 to 1016 for the $m b o B$ gene, and AGGA at 1855 to 1858 for the $m b o C$ gene. A putative promoter sequence upstream of the mboA gene resembled the E.coli consensus sequence; a -35 box, TTGTAA, at positions 61 to 66 and a -10 box, TATAAT, at positions 92 to 97 . The GC content of the three genes was about $30 \%$, which was lower than the median of $M$. bovis [41.0-44.5\%, (4)]. The $\mathrm{G}+\mathrm{C}$ content is low in the genes of the MboII system, also (6).

\section{Overproduction of R.MboI}

The MboI system, which had two methyltransferases, M.MboA and M.MboC, was similar to the DpnII system, because both systems recognized the same sequence and both had two methyltransferases. If the two methylases of the $M b o I$ system had the same functions as those of the DpnII system, one of the two proteins might help to regulate system activation. We constructed two plasmids, named pMBOC and pMBOAB, for expression of the R.MboI gene (Figs. 2A and B). The strain obtained by transformation, E.coli-MBOI, overproduced R.MboI. A polypeptide with the $M_{r}$ of 31,000 was overproduced; this was probably R.MboI (Fig. 2C). A band at $M_{r} 26,000$ (Fig. 2C, lanes 5 to 8 ) is likely to be a translational product of the chloramphenicol resistance gene. In vitro R.MboI activity in a crude extract from heat-induced E.coli-MBOI was $1,200,000 \mathrm{U} / \mathrm{g}$ cells, which was 480 -fold that from $M$.bovis.

We also transformed $E$. coli with pMBOAB and pNT203, and this strain overproduced R.MboI, as well. However, the mboB and $m b o C$ genes could not be cloned in $E$. coli without the $m b o A$ gene. These findings indicate that $\mathrm{M} \cdot \mathrm{MboC}$ might be a weaker and less specific methylase than M.MboA; the DpnII system also has a pair of methylases different in this way (9).

\section{Comparison of amino acid sequences}

The deduced amino acid sequences of the MboI system were compared with the sequences of other restriction-modification systems published in the Gene/Protein database. The protein sequence of M.MboA was $44 \%$ homologous with that of M.DpnII (9) and 34\% homologous with that of E.coli Dam methylase (10). No homology was found between the sequences of M.MboA and M.MboC, which enzymes recognized and methylated the same DNA sequence. The sequence of $\mathrm{M} . \mathrm{MboC}$ had $49 \%$ homology with that of DpnA (8) and 35\% homology with that of M.Hinfl $(26,27)$. The best alignments of the sequences of M.MboA, M.DpnII, and E. coli Dam methylase (group I) and of M.MboC, DpnA, and M.Hinfl (group II) are shown in Figs. 3A and B. There were four and five highly homologous regions in the sequences of group I and II methylases, respectively (boxes $\underline{a}$ to $\underline{i})$. The $\underline{b}$ and $\underline{i}$ regions probably contained the binding site of $S$-adenosylmethionine $(28,29)$. The $\underline{d}$ and $\underline{e}$ regions containing the DPPY motif might be involved in the methylation of exocyclic amino acids (30). We cannot explain why regions other than $\underline{b}, \underline{i}, \underline{d}$, and $\underline{e}$ were conserved.

The M.MboA and M.MboC protein sequences were homologous with the T4 Dam methylase (31) and M.EcoRV (32) sequences or with the M.MboII (6) and M.HpaI (33) sequences, respectively. The only characteristic shared by these methylases was that they are $\mathrm{N}^{6}$-adenine methylases.

The R.MboI protein sequence had homology (38\%) with the R.DpnII sequence only (9). Five highly homologous regions (Fig. 3C, boxes with $\mathrm{j}$ to $\mathrm{n}$ ) were found between the two protein sequences. R.MboI recognizes and cleaves the same DNA sequence as R.DpnII. Therefore, the homologous regions were probably involved in the specificities of these enzymes. 


\section{ACKNOWLEDGEMENTS}

We thank Mr. T.Tanigawa of Bioproducts Development Center, Takara Shuzo Co., Ltd., for N-terminal amino acid sequence analysis.

\section{REFERENCES}

1. Roberts, R.J. (1990) Nucleic Acids Res., 18, s2331-s2365.

2. Wilson, G.G. (1991) Nucleic Acids Res., 19, 2539-2565.

3. Wilson, G.G. and Murray, N.E. (1991) Annu. Rev. Genet., 25, 585-627.

4. Krieg, N.R. and Holt, J.G., eds. Bergey's Manual of Systematic Bacteriology, Williams \& Wilkins, Baltimore, Vol. 1, p. 301.

5. Gelinas, R.E., Myers, P.A. and Roberts, R.J. (1977) J. Mol. Biol., 114, $169-179$.

6. Bocklage, H., Heeger, K. and Müller-Hill, B. (1991) Nucleic Acids Res., 19, $1007-1013$.

7. Seeber, S., Kessler, C. and Götz, F. (1990) Gene, 94, 37-43.

8. Lacks, S.A., Mannarelli, B.M., Springhorn, S.S. and Greenberg, B. (1986) Cell, 46, 993-1000.

9. de la Campa, A.G., Kale, P., Springhorn, S.S. and Lacks, S.A. (1987) J. Mol. Biol., 196, 457-469.

10. Brooks, J.E., Blumenthal, R.M. and Gingeras, T.R. (1983) Nucleic Acids Res., 11, 837-851.

11. Marinus, M.G. and Morris, N.R. (1973) J. Bacteriol., 114, 1143-1150.

12. Boyer, H.W. and Roulland-Dussoix, D. (1969) J. Mol. Biol., 41, 459-472.

13. Yanisch-Perron, C., Vieira, J. and Messing, J. (1985) Gene, 33, 103-119.

14. Bolivar, F., Rodriguez, R.L., Greene, P.J., Betlach, M.C., Heyneker, H.L., Boyer, H.W., Crosa, J.H. and Falkow, S. (1977) Gene, 2, 95-113.

15. Chang, A.C.Y. and Cohen, S.N. (1978) J. Bacteriol., 134, 1141-1156.

16. Maki, H., Horiuchi, T. and Sekiguchi, M. (1983) Proc. Natl. Acad. Sci. USA, 80, 7137-7141.

17. Shigesada, K., Tsurushita, N., Matsumoto, Y. and Imai, M. (1984) Gene, 29, 199-209.

18. Hanahan, D. (1983) J. Mol. Biol., 166, 557-580.

19. Birnboim, H.C. and Doly, J. (1979) Nucleic Acids Res., 7, 1513-1523.

20. Ausubel, F.M., Brent, R., Kingston, R.E., Moore, D.D., Seidman, J.G., Smith, J.A. and Struhl, K., eds. (1987) Current Protocols in Molecular Biology. John Wiley, New York, Vol. 1.

21. Sambrook, J., Fritsch, E.F. and Maniatis, T. (1989) Molecular Cloning: a Laboratory Manual. Cold Spring Harbor Laboratory Press, Cold Spring Harbor, New York.

22. Matsudaira, P. (1987) J. Biol. Chem., 262, 10035-10038.

23. Ito, H., Sadaoka, A., Kotani, H., Hiraoka, N. and Nakamura, T. (1990) Nucleic Acids Res., 18, 3903-3911.

24. Sanger, F., Nicklen, S. and Coulson, A.R. (1977) Proc. Natl. Acad. Sci. USA, 74, 5463-5467.

25. Laemmli, U.K. (1970) Nature, 227, 680-685.

26. Chandrasegaran, S., Lunnen, K.D., Smith, H.O. and Wilson, G.G. (1988) Gene, 70, 387-392.

27. Lauster, R. (1989) Nucleic Acids Res., 17, 4402.

28. Lauster, R., Trautner, T.A. and Noyer-Weidner, M. (1989) J. Mol. Biol., 206, 305-312.

29. Lauster, R. (1989) J. Mol. Biol., 206, 313-321.

30. Klimasauskas, S., Timinskas, A., Menkevicius, S., Butkiene, D., Butkus, V. and Janulaitis, A. (1989) Nucleic Acids Res., 17, 9823-9832.

31. Schlagman, S.L. and Hattman, S. (1983) Gene, 22, 139-156.

32. Bougueleret, L., Schwarzstein, M., Tsugita, A. and Zabeau, M. (1984) Nucleic Acids Res., 12, 3659-3676.

33. Ito, H., Shimato, H., Sadaoka, A., Kotani, H., Kimizuka, F. and Kato, I. (1992) Nucleic Acids Res., 20, 705-709. 